\title{
Protective effect of respiratory devices in farmers with occupational asthma
}

\author{
D. Müller-Wening, M. Neuhauss
}

Protective effect of respiratory devices in farmers with occupational asthma. D. MüllerWening, M. Neuhauss. (CERS Journals Ltd 1998.

ABSTRACT: To the authors' knowledge there have been no previous reports on the protection afforded by powered filtering respirators in farmers with occupational asthma attributed to the inhalation of organic dust.

In order to investigate this question, 26 farmers with occupational asthma were challenged with an exposure to work-related dusts for up to $60 \mathrm{~min}$. This resulted in highly significant increases in airway resistance $(R a w)$, thoracic gas volume (TGV) and specific airway resistance (sRaw) compared to baseline values.

After a mean period of 21 weeks the farmers were subjected to a second challenge, this time wearing a protective respiratory device (RD) with a P2 filter. Significant increases in $R$ aw, TGV and sRaw were again observed, but on average these were 50$80 \%$ smaller than the increases seen when RDs were not worn. These differences were found to be statistically significant.

This shows that the use of a respiratory device in farmers suffering from occupational asthma reduces the development of bronchial obstruction but does not prevent it. The use of this kind of respiratory device cannot substitute for the proper management of asthma since the devices do not offer complete protection.

Eur Respir J 1998; 12: 569-572.
Zusamklinik der LVA Schwaben, Zusmarshausen, Germany.

Correspondence: D. Müller-Wening

Zusamklinik der LVA Schwaben

Paracelsusstr. 3

D-86441 Zusmarshausen

Germany

Fax: 4982918382

Keywords: Asthma

farmer

prevention

respiratory protective device

Received: October 201997

Accepted after revision May 51998
Among farmers, the prevalence of chronic bronchitis and asthma is higher than in the general population [1-3]. This phenomenon is due to the influence of immunological and nonimmunological components of organic dusts $[4,5]$. Particular importance is attached to the endotoxins [6-8]. Reduced exposure to organic dusts is an important preventive measure $[9,10]$. The utilization of a personal respiratory device (RD) is a common method of cleaning contaminated air [11]. Farmers suffering from respiratory symptoms tend to wear RDs more frequently than farmers without these symptoms [12]. However, it has been shown that even the use of RDs with P2 and P3 filters did not protect patients with farmer's lung; they developed systemic and pulmonary reactions after a challenge [13, 14]. It has also been demonstrated that flour-dust asthmatics [15], pig farmers [16, 17], grain workers [18, 19], subjects suffering from laboratory animal allergy [20], and patients with a cedar allergy [21] cannot receive complete protection using RDs. This failure has been blamed on filter- and face-seal leaks. LACEY et al. [22] demonstrated that filters allow penetration of $0.1-3.1 \%$ of actinomycete spores, depending on design. ManNinen et al. [23] demonstrated face-seal leakages of $2.4-3.4 \%$ in RDs.

The present study examined whether RDs have a protective effect on farmers with occupational asthma.

\section{Methods}

Twenty-six farmers from southern Bavaria with suspected occupational asthma were examined. The sample com-

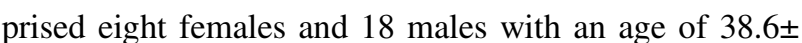
$11.8 \mathrm{yrs}($ mean $\pm \mathrm{SD})$. Four of the females and six of the males were smokers. All 26 subjects were involved in dairy farming and/or bull breeding either using conventional straw bedding and mucking out by hand or working with manure. They all came in contact with grain dust, hay and straw daily and had been exposed to these conditions for a mean duration of $34 \pm 14.9$ yrs. Health problems had been present for a mean of $9.1 \pm 6.8$ yrs. The average daily duration of exposure to agricultural dust lasted up to $4 \mathrm{~h}$. After the farmers had been exposed to hay, straw or grain dust, all of them suffered from coughing, dyspnoea and wheezing breath. Six of them had a history of atopy. A physical examination revealed no deviation from what is considered to be normal. The mean total serum immunoglobulin $(\mathrm{Ig}) \mathrm{E}$ level was $325 \pm 403 \mathrm{IU} \cdot \mathrm{mL}^{-1}$. The mean serum levels of $\operatorname{IgG}, \operatorname{IgM}, \operatorname{IgA}$ and $\alpha_{1}$-antitrypsin were within normal limits. Table 1 shows the results of the lung-function tests of the 26 farmers at the time of their admission as inpatients. The patients were taking no antiinflammatory or bronchodilatory medicine at the time of the investigations.

In all patients, nonspecific bronchial reactivity was tested. A test was rated positive if the specific airway resistance ( $\mathrm{s} R \mathrm{aw}$ ) rose to at least twice the baseline value and the absolute value became $\breve{S} 2.0 \mathrm{kPa} \cdot \mathrm{s}^{-1}$. None of the patients showed a significant rise in $\mathrm{s} R$ aw following the inhalation of physiological saline and lactose powder. Eleven of the farmers experienced a positive reaction after they had inhaled $1 \mathrm{~mL}$ of a $0.3 \%$ solution of histamine, four 
Table 1. - Lung function parameters at the time of admission in the 26 farmers investigated

\begin{tabular}{lccc}
\hline & Mean \pm SD & Minimum & Maximum \\
\hline$R$ aw kPa $\cdot \mathrm{s}^{-1} \cdot \mathrm{L}^{-1}$ & $0.31 \pm 0.10$ & 0.18 & 0.53 \\
TGV L & $3.77 \pm 1.05$ & 2.01 & 6.15 \\
SRaw kPa $\cdot \mathrm{s}^{-1}$ & $1.18 \pm 0.42$ & 0.59 & 2.09 \\
TLC L & $7.06 \pm 1.43$ & 4.16 & 9.82 \\
VC L & $4.65 \pm 1.19$ & 2.58 & 6.97 \\
FEV $1 \mathrm{~L} \cdot \mathrm{s}^{-1}$ & $3.46 \pm 0.95$ & 1.84 & 5.00 \\
\hline
\end{tabular}

$R$ aw: airway resistance: TGV: thoracic gas volume; $\mathrm{s}$ aw: specific airway resistance; TLC: total lung capacity; VC: vital capacity; FEV 1: forced expiratory volume in one second.

after $1 \mathrm{~mL}$ of a $1 \%$ solution of histamine, 10 after eucapnic hyperventilation with cold air $\left(70 \mathrm{~L} \cdot \mathrm{min}^{-1},-21.6^{\circ} \mathrm{C}\right)$ and one after having exercised on a bicycle ergometer. During the allergy examination, every patient showed at least one positive histamine-like skin reaction and/or produced specific IgE antibodies of radioallergosorbent tests (RAST) category II or higher against occupational allergens. The patients gave their informed consent to the performance of inhalation challenge tests.

The tests took place in the hospital in a room of $54 \mathrm{~m}^{3}$ under similar conditions to those found in the patients' workplace. During the provocation, the farmers had to whirl up about $5 \mathrm{~kg}$ of material they had brought along, which was considered to be causative. According to the farmers the resulting dusty atmosphere corresponded to the circumstances in the barns and stables. During two hay provocations respirable dust concentrations of 7.05 and $6.38 \mathrm{mg} \cdot \mathrm{m}^{-3}$ were measured.

Each of the patients had to undergo two inhalative challenges, one with and one without an RD. Fourteen of the farmers were tested with hay, five with straw, four with both hay and straw, two with grain dust and one with hay, straw and grain dust. On average, the second challenge, with the patients wearing respirators, was performed 21 weeks after the first positive test and the same materials were used as in the first challenges. Twenty-one of the patients used a "Dustmaster" with a P2 filter, four used an "Airstream helmet" with a P2 filter and one of them used an "Airlite" respiratory device with a P2 filter (all three respiratory devices produced by Racal, Dietzenbach, Germany).

Before each provocation a short history of the patient was taken and physical examination and body plethysmography were carried out. During the provocations which lasted for a maximum of $60 \mathrm{~min}$, the farmers were ques- tioned and auscultated and a body plethysmograph was carried out every $15 \mathrm{~min}$. A test was rated positive if the $\mathrm{s} R$ aw rose to at least twice the baseline value and if the absolute value became $\breve{S} 2.0 \mathrm{kPa} \cdot \mathrm{s}^{-1}$. The provocation was terminated and bronchodilator treatment was given if these criteria for discontinuation were attained. The patients were observed for up to $8 \mathrm{~h}$ after the beginning of the test.

\section{Statistical analysis}

Mean values and standard deviations were calculated from the data. Two means were compared using the Student's t-test, paired for intraindividual and unpaired for interindividual comparisons. A p-value $<0.05$ was regarded as significant and a p-value $<0.01$ as highly significant.

\section{Results}

A highly significant rise in airway resistance ( $R \mathrm{aw}$ ), $\mathrm{s} R$ aw and intrathoracic gas volume (TGV) was observed in the challenges without RDs compared to baseline values. When RDs were worn, the challenges again caused highly significant increases in Raw, sRaw and TGV. Table 2 shows the results of the double-challenge tests with and without the respirators being worn. The peak values of $R$ aw, $s R$ aw and TGV observed under the two conditions were compared statistically with each other and with baseline values.

Figure 1 shows the time course of $s$ aw. When the prechallenge values of $R$ aw, $s R$ aw and TGV were compared statistically, no significant differences could be found. Using no RDs all of the farmers complained of coughing and dyspnoea and, when they were auscultated, wheezing could be heard. After these challenges all farmers received bronchodilatory treatment. In the challenge with RDs six of the 26 patients required bronchodilatory treatment because they had reached the criteria for discontinuation. Eleven of the farmers examined stated that they had no breathing difficulties when using an RD and the remaining 15 reported a reduction in their complaints.

The mean difference in increase in Raw between the two tests was $0.25 \mathrm{kPa} \cdot \mathrm{s}^{-1} \cdot \mathrm{L}^{-1}$, and the mean difference in increase in $\mathrm{s}$ aw was $1.66 \mathrm{kPa} \cdot \mathrm{s}^{-1}$. These differences were statistically highly significant. The mean difference in the rise in intrathoracic gas volume was $0.72 \mathrm{~L}$ and was significant at the $4 \%$ level.

Table 2. - Airway resistance (Raw), specific airway resistance (sRaw) and thoracic gas volume (TGV) in 26 double-challenge tests with and without respiratory protection

\begin{tabular}{|c|c|c|c|}
\hline & $\begin{array}{l}\text { Without } \\
\text { respiratory } \\
\text { function }\end{array}$ & $\begin{array}{l}\text { With } \\
\text { respiratory } \\
\text { function }\end{array}$ & p-value \\
\hline \multicolumn{4}{|l|}{$R$ aw $\mathrm{kPa} \cdot \mathrm{s}^{-1} \cdot \mathrm{L}^{-1}$} \\
\hline Prechallenge & $0.30 \pm 0.08$ & $0.30 \pm 0.1$ & NS \\
\hline Maximum postchallenge & $0.74 \pm 0.13 * * *$ & $0.49 \pm 0.24 * * *$ & $<0.001$ \\
\hline \multicolumn{4}{|l|}{$\mathrm{s} R$ aw $\mathrm{kPa} \cdot \mathrm{s}^{-1}$} \\
\hline Prechallenge & $1.19 \pm 0.37$ & $1.24 \pm 0.49$ & NS \\
\hline Maximum postchallenge & $3.75 \pm 1.12 * * *$ & $2.13 \pm 1.26 * * *$ & $<0.001$ \\
\hline \multicolumn{4}{|l|}{ TGV L } \\
\hline Prechallenge & $3.81 \pm 1.03$ & $3.91 \pm 0.88$ & NS \\
\hline Maximum postchallenge & $5.06 \pm 1.08 * * *$ & $4.43 \pm 1.04 * * *$ & $<0.04$ \\
\hline
\end{tabular}

Data are mean \pm SD. $* * *: \mathrm{p}<0.001$, significant difference between prechallenge and postchallenge values. 

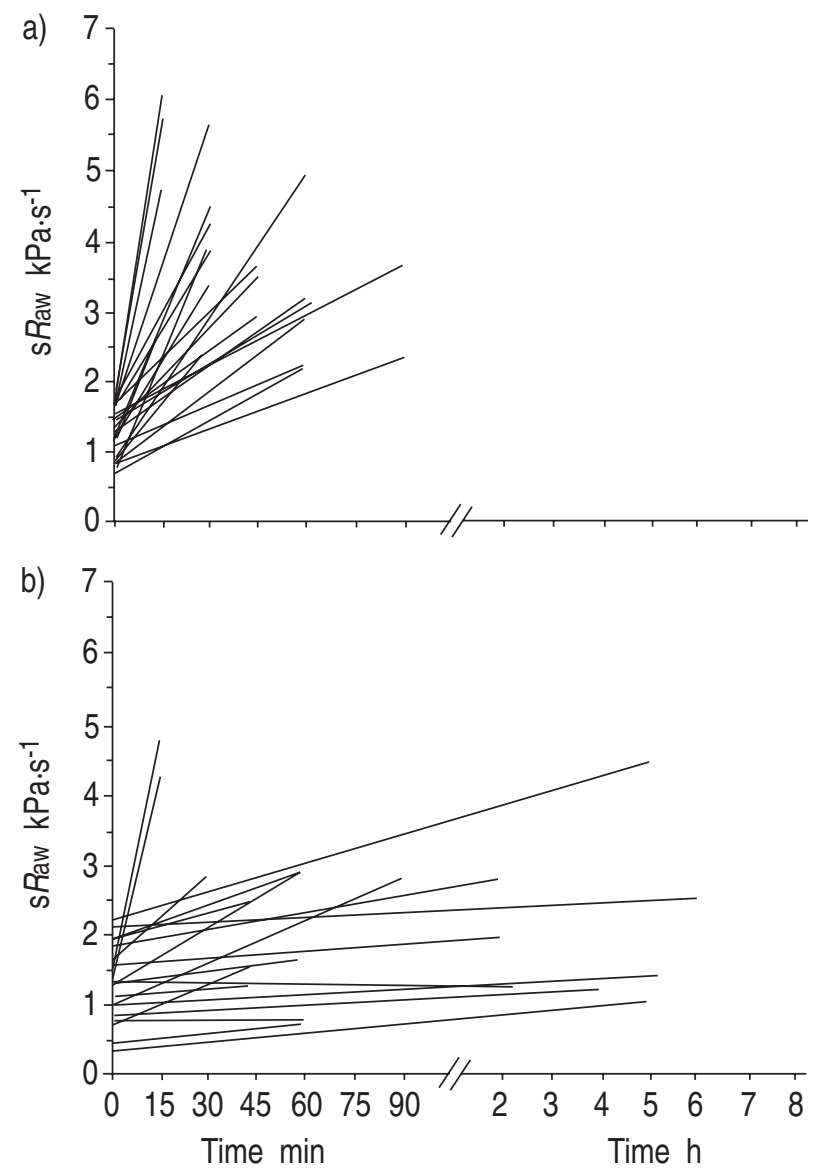

Fig. 1. - Time course of specific airway resistance ( $R$ aw) in 26 doublechallenge tests a) without and b) with respiratory protection. The end of the lines indicate the point at which the criteria for discontinuation or the maximum response after provocation were reached.

As a group, the six farmers who reached the criteria for discontinuation when using an RD were not different from the others in terms of bronchial reactivity, the kind of RD worn, age, sex, or duration of exposure.

\section{Discussion}

The main result of this study was that the use of respiratory devices in farmers with occupational asthma significantly reduced the degree of bronchial obstruction, but did not provide complete protection. This was shown in 26 farmers by work-related inhalation challenge tests with natural materials. In the tests without RDs all patients experienced symptoms and their $R$ aw, $\mathrm{s}$ aw and TGV rose in a statistically highly significant way. A highly significant increase in these three parameters, compared with the baseline values, was also observed in tests using an RD, but these increases were, on average 57\% (Raw), 60\% (TGV) and 77\% (sRaw) less than those observed when RDs were not worn. Fifteen of the 26 farmers complained of problems even when they had worn an RD and six of these required bronchodilatory treatment.

These patients were male and female farmers working on small farms where the farmer and their spouse accomplished all of the work together. It was hardly possible for them to delegate the dusty work to someone else. From the allergological point of view changing their profession would be necessary, but for economic reasons almost none of the affected asthmatics could do so.

In order to reduce morbidity, organizational and hygiene measures at the workplace should be considered at an early stage, because some of the affected persons suffering from occupational asthma will face a worsening of their complaints if their exposure continues. Another reason for taking early measures is the fact that asthma improves in only half of the patients after exposure has been reduced [20, 24].

In Germany, agricultural compensation boards provide powered RDs (using a P2 Filter) to the affected persons as a measure of secondary prevention. These RDs eliminate $90 \%$ of all particles $>0.5 \mu \mathrm{m}$.

Measurements showed that the dust concentration used in the provocations represented the occupational conditions in a realistic way. VOGELMEIER et al. [25] measured total dust concentrations of $100 \pm 54.3 \mathrm{mg} \cdot \mathrm{m}^{-3}$ and respi-rable dust concentrations of $34.8 \pm 19.2 \mathrm{mg} \cdot \mathrm{m}^{-3}$ during a workrelated hay challenge. During hay work in barns they measured total dust concentrations of $36.1 \pm 24.5 \mathrm{mg} \cdot \mathrm{m}^{-3}$ and respirable dust concentrations of $14.6 \pm 12.7 \mathrm{mg} \cdot \mathrm{m}^{-3}$. In the present study respirable dust concentrations of 6.38 and $7.05 \mathrm{mg} \cdot \mathrm{m}^{-3}$ were measured. Do PIco [26] reported that, in grain elevators, total airborne dust concentrations ranged from $<10-780 \mathrm{mg} \cdot \mathrm{m}^{-3}$ [26]. LouheLAINEN et al. [27] measured total dust concentrations of up to $60.2 \mathrm{mg} \cdot \mathrm{m}^{-3}$ during farm work. SchWARTZ et al. [5] showed that workrelated respiratory symptoms were more closely associated with the concentration of endotoxin in the bioaerosol of the work setting than with the total dust concentration. In the farm environment endotoxin levels vary from $0.01-$ $100 \mu \mathrm{g} \cdot \mathrm{m}^{-3}[26,28]$.

Using natural materials did not allow differentiation between specific and nonspecific airway obstruction, but provided the opportunity to investigate the efficacy of RDs. The tests were evaluated according to the recommendations of the Deutsche Gesellschaft für Allergie- und Immunitätsforschung [29].

The present study shows that the use of an RD with a P2 filter fails to prevent the development of symptomatic bronchial obstruction in most sensitized farmers exposed to work-related dust. Having performed investigations among persons with laboratory animal allergy, SLOVAK et al. [20] doubted that using an Airstream helmet could prevent the worsening of asthma. In persons exposed to grain dust, the utilization of RDs did not cause a decrease in symptoms or changes in lung function $[16,19]$. It has been demonstrated among patients suffering from farmer's lung that the use of an RD cannot avoid the allergic reaction completely when the farmers are exposed to appropriate allergens [13] and acute febrile reactions may even occur [14]. It has also been shown that, among persons suffering from flour-dust asthma, RDs could not protect all patients who were exposed [15].

This failure to protect all exposed subjects has to be attributed to filter- and face-seal leaks [10, 22, 23]. The present investigation allows the conclusion to be drawn that the use of respiratory devices with $\mathrm{P} 2$ filters in farmers suffering from occupational asthma can reduce the development of bronchial obstruction during an acute exposition but cannot prevent it. The influence of the use 
of respiratory devices on the long-term outcome of patients with occupational asthma could not be answered by this study. Longitudinal studies should be conducted to answer this question.

\section{References}

1. Bousquet $\mathrm{J}$, Vergnenègre A. Agricultural asthma. In: Michel RB, Bousquet J, Godard P, eds. Highlights in Asthmology. Berlin, Springer, 1987; pp. 331-342.

2. Chan-Yeung M, Enarson DA, Kennedy SM. The impact of grain dust on respiratory health. Am Rev Respir Dis 1992; 145: 476-487.

3. Rask-Anderson A, Lundin A. A 12-year follow-up of respiratory disease in farmers. Tubercle Lung Dis 1995; 76: S56.

4. Donham KJ. Respiratory disease hazards to workers in livestock and poultry confinements structures. Semin Respir Med 1993; 14: 49-59.

5. Schwartz DA, Thorne PS, Yagla SJ, et al. The role of endotoxin in grain dust-induced lung disease. Am J Respir Crit Care Med 1995; 152: 603-608.

6. Huy T, De Schipper K, Chan-Yeung M, Kennedy SM. Grain dust and lung, function. Am Rev Respir Dis 1991; 144: 1314-1321.

7. Rylander R. Organic dusts and cell reactions. Semin Respir Med 1993; 14: 15-19.

8. Zejda JE, Barber E, Dosman JA, et al. Respiratory health status in swine producers relates to endotoxin exposure in presence of low dust levels. J Occup Med 1994; 36: 4956.

9. Clark S. Report on prevention and control. Am J Ind Med 1986; 10: 267-273.

10. Pickrell JA, Heber AJ, Murphy JP, et al. Total and respirable dust in swine confinement buildings: the benefit of respiratory protective masks and effect of recirculated air. Vet Hum Toxicol 1995; 37: 430-435.

11. Bauer MA, Coppolo DP. Agricultural lung disease: prevention. Semin Respir Med 1991; 14: 83-89.

12. Corey P, Hutcheon M, Broder I, Mintz S. Grain elevator workers show work-related pulmonary function changes and dose-effect relationships with dust exposure. Br J Ind Med 1982; 39: 330-337.

13. Müller-Wening D, Repp H. Investigation on the protective value of breathing masks in farmer's lung using an inhalation provocation test. Chest 1989; 95: 100-105.

14. Nuutinen J, Terho EO, Husman K, et al. Protective value of powered dust respirator helmet for farmers with farmer's lung. Eur J Respir Dis 1987; 152: 212-220.

15. Woitowitz H. Zur Schutzwirkung einer partikelfiltrierenden Leichtmaske gegenüber Mehlstaub. Staub 1986; 46: 239-242.

16. Bongers P, Houthuijs D, Remijn B, Brouwer R, Biersteker K. Lung function and respiratory symptoms in pig farmers. Br J Ind Med 1987; 44: 819-823.

17. Zejda JE, Hurst TS, Barber EM, Rhodes C, Dosman JA. Respiratory health status in swine producers using respiratory protective devices. Am J Ind Med 1993; 23: $743-$ 750.

18. Cockroft AE, McDermott M, Edwards JH, McCarthy P. Grain exposure - symptoms and lung function. Eur $J$ Respir Dis 1983; 64: 189-196.

19. McCarthy PE, Cockroft AE, McDermott M. Lung function after exposure to barley dust. Br J Ind Med 1985; 42: 106-110.

20. Slovak AJM, Orr RG, Teasdale EL. Efficacy of the helmet respirator in occupational, asthma due to laboratory animal allergy. Am Ind Hyg Assoc J 1985; 46: 411-415.

21. Cote J, Kennedy S, Chan-Yeung M. Outcome of patients with cedar asthma with continuous exposure. Am Rev Respir Dis 1990; 141: 373-376.

22. Lacey J, Nabb S, Webster BT. Retention of actinomycete spores by respirator filters. Ann Occup Hyg 1982; 25 : 351-363.

23. Manninen A, Klen T, Pasanen P. Evaluation of comfort and seal leakages of several respirators used in agricultural work. Am Ind Hyg Assoc J 1988; 49: 280-285.

24. Grammer LC, Shaughnessy MA, Henderson J, et al. A clinical and immunological study of workers with trimellitic-anhydride immunologic lung disease after transfer to low exposure jobs. Am Rev Respir Dis 1993; 148: 54-57.

25. Vogelmeier C, Baur X, König G, Mauermayer R, Frumann G. Der Heustaubexpositionstest in der diagnostik der farmerlunge: staubmessungen und testungen von kontrollpersonen. Prax Klin Pneumol 1988; 42: 749-752.

26. do Pico GA. Hazardous exposure and lung disease among farm workers. Clin Chest Med 1992; 13: 311-328.

27. Louhelainen K, Kangas J, Husman K, Terho OE. Total concentrations of dust during farm work. Eur J Respir Dis 1987; 152: 73-79.

28. Zejda JE, Dosman JA. Respiratory disorders in agriculture. Tubercle Lung Dis 1993; 74: 74-86.

29. Gonsior E. Bronchiale und nasale provokationstests. Allergologie 1984; 7: 238-242. 